\title{
Primary nurse experiences in applying primary method: a phenomenology study
}

\begin{abstract}
Primary nursing care method in Indonesia new, only several hospital try to execute it, one of which is west Sumatra Hospital implemented in neurology ward have been applying for 3 years, before neurology room in west sumatra Hospital applied team method. The purpose of this research is to know primary nurse experience in applying primary method in neurology ward, West Sumatra Hospital, Bukittinggi. The design of this research is qualitative with phenomenology approach, data collection was used by deep interview. The respondents were taken by total sampling, the amount are 5 people, that consists of 1 person of magister nurse and 4 people of undergraduate nurse. Data analyses was used Collaizi. The result showed 4 themes, ability to manage patients, competent care for patients and nurse satisfaction and needs flexibility to schedule service. It is hoped that Hospital make policy for nurses to continue their education, training about primary nursing care method.
\end{abstract}

Keywords: primary nurse, primary method
Volume 4 Issue 2 - 2017

Ratna Dewi, Yati Afiyanti, Atih Rahayuningsih
Faculty of Nursing, Andalas University, Indonesia

Correspondence: Ratna Dewi, Faculty of Nursing, Andalas University, Indonesia, Email ratnadewi25I I83@g.mail.com

Received: July 21, 2017 | Published: October 25, 2017

\section{Preliminary}

Nursing is a professional service as an integral part of health care. Professional nursing services can be realized if implemented by professional nursing staff so as to contribute in improving the quality of hospital services specifically nursing services. ${ }^{1}$ Implementation nursing management cannot be separated from the implementation of management functions effectively and efficiently. Terry suggests that management functions include four functions: planning, organizing, actuating and controlling. Each management function is interconnected with each other and can be applied by both upper, middle and lower managers. In the range of nursing can be applied ranging from Head of Nursing to Head of Room. ${ }^{2}$

The Head Room performs a nursing management function which includes nursing service management and nursing care management. Implementation of nursing care management is supported by the organization of nursing care through methods of nursing care as part of the organizing function. ${ }^{3}$ Marquis and Huston further argue that the components of organizing functions include organizational structure, methods of nursing care, grouping activities to achieve goals, working within the organizational structure by understanding the strength and authority. Thus it is clear that the method of nursing care is part of the organizing fungtion. The Professional Nursing Care Method is as a system (structure, process and values) that enables professional nurses to manage nursing care including the environment to support the provision of care. ${ }^{4}$ The method of nursing care consists of five methods which include functional method, case method, team nursing, modular method and primary nursing., ${ }^{3,5}$ Each method of providing nursing care has its advantages and disadvantages as an example of one of the primary excesses of the primary nurse is that it is highly accountable for the results and allows for self-development and its weaknesses can only be done by professional nurses. ${ }^{3}$

One method of giving nursing care that is used is the method of providing primary care kaperawatan. The method of giving primary nursing care is an assignment method in which one nurse takes full responsibility for 24 hours of nursing care from patient admission until patient out of hospital. This primary method is characterized by a strong and continuous linkage between patients and nurses assigned to plan, perform and coordinate nursing care during patient care. ${ }^{4}$ The method of nursing care used is the method of giving primary nursing care on the grounds to improve the quality of nursing service, patient satisfaction and nurse satisfaction. The result of the research conducted by Setyowati ${ }^{6}$ proves that there is an increase of nurse performance in the Bhayangkara Kediri Hospital which get intervention and apply the method of assigning the primary team modification and the difference of nurse performance in the inpatient ward that applies the method of assigning the primary team modification with the non apply.

The study was also conducted by Adriani ${ }^{7}$ on nurses' job satisfaction on primary team application method in the implementation of nursing care actions in RS. Dr. Saiful Anwar Malang obtained the result that working conditions greatly affect job satisfaction. The result of interview with Nursing Section and nurse of Inpatient Neurology Hospital of West Sumatra Hospital of Bukittinggi then got the phenomenon that total nursing personnel 31 people with bed capacity of 34 Bed in room and 3 bed in High Care Unit room. Nursing workers in the neuro room are mostly D3 Nursing (29 people), S1 Nursing ( 9 persons), S2 Nursing (1 person). Level of education head of nursing neuro nursing, primary education nursing master level 1 person and 4 nursing undergraduate. The method of providing primary nursing care in Neurology Inpatient Installation has been running for 3 years, previously the neurology room of West Sumatra Hospital using team method. Other rooms to date still use team methods (personal communication, 26-27 February).

In the neurological inpatient room the method of nursing care carried out is the primary method according to SK by the director of the West Sumatra Hospital of Bukittinggi, but in terms of the majority of nursing staff with the level of Nursing D3 education. Due to the limited energy and education majority of D3 nursing, primary nurses manage patient's 8-9 people. From the organizational structure is already illustrated the existence of karu, below the primary nurse and under the primary nurse is nurse associate or nurse executor, primary nurse has responsibility from start of patient enter until patient out. 
In the neurological wards the implementation of the nursing care method implemented is the primary method according to the SK by the director of the Hospital West Sumatra Bukittinggi, but in terms of nursing power majority with D3 Nursing education level. Due to the limited energy and education majority of D3 nursing, primary nurses manage patients 8-9 people. From the organizational structure is already illustrated the existence of karu, below the primary nurse and under the primary nurse is nurse associate or nurse executor, primary nurse has responsibility from start of patient enter until patient out. Based on these data it can be seen that existing nursing staff have varying levels of education and competence. In addition there is a higher level of education and competence that can guide the nursing staff with lower levels of competence. This situation provides a good opportunity to use the primary method.

Research on Study The phenomenon of primary nurses in applying the primary method has never been done in the Neurology Hospital of Bukittinggi West Sumatra Hospital. Based on the above phenomenon, the researchers are interested and feel the need to conduct research with the title of study of primary nurse phenomenon in applying the primary method has never been done in inpatient room Neurology Hospital of West Sumatra Bukittinggi.

\section{Method}

This research is about experience of primary nurse in applying nursing care of primary method using phenomenology method. Phenomenology is a model of qualitative research related to a phenomenon, an individual experience that can be examined for a phenomenon experienced in daily life. ${ }^{8}$ This research is about experience of primary nurse in applying nursing care of primary method using phenomenology method. Phenomenology is a model of qualitative research related to a phenomenon, an individual experience that can be examined for a phenomenon experienced in daily life. ${ }^{8}$

This design is appraised precisely because this study will reveal the primary care experience in providing primary nursing care. This research is used to capture and describe a phenomenon about the experience of primary nurses in applying nursing care of primary methods and to exploit the phenomenon and to provide an explanation of a phenomenon under study. This is in line with Moleong ${ }^{9}$ revealed that qualitative research is done to understand the phenomenon of what experienced subjects.

Participants in this study were all primary nurses who were in the neurological ward of the West Sumatra Hospital of Bukittinggi. The number of primary nurses in the neurological ward of Bukittinggi West Sumatra Hospital is as many as 5 people. All the populations were subjected to research. Sampling method is sample of total population that is sampling in all population or participant. ${ }^{8}$ This research has been carried out at the Neurological Inpatient Room of RSSN Bukittinggi. The reason for taking this room is because the room is the only neurological room that uses the Primary Method Research has been conducted from June to July 2014, while the development of proposals up to the preparation of research results approximately lasted for six months from februari to August.

\section{Research result}

Participants in this in-depth interview were the primary nurses in the Neurology Room of Bukittinggi West Sumatra Hospital, numbering five, serving as primary nurses in the neurology room of the West Sumatra hospital. The average age of participants in in-depth interviews is 39 years, with experience of being a primary nurse of 2-3 years. The level of education for the in-depth interview participants is nursing S1 amounted to 4 people and 1 nursing S2 Table 1.

Table I Characteristics of participants research studies phenomena experience primary nurses in applying the primary method

\begin{tabular}{llllll} 
No & $\begin{array}{l}\text { Participant } \\
\text { initials }\end{array}$ & Age & Gender & Education & $\begin{array}{l}\text { Experience } \\
\text { of being a } \\
\text { primary } \\
\text { nurse }\end{array}$ \\
\hline I & PI & 37 Tahun & Women & S2 Nursing & I Tahun \\
2 & P2 & 4I Tahun & Women & SI Nursing & 3 Tahun \\
3 & P3 & 49 Tahun & Women & SINursing & 2 Tahun \\
4 & P4 & 35 Tahun & Women & SI Nursing & 2,5 Tahun \\
5 & P5 & 36 Tahun & Women & SI Nursing & 3 Tahun \\
\hline
\end{tabular}

\section{Theme}

The theme in this study was obtained through in-depth interviews with participants. From result of data analysis, researchers get 3 cluster themes that explain problem of researcher. The theme clusters obtained on nursing experiences in applying primary nursing care methods are:

i. The ability to manage patients

ii. Competent care for patients

iii. Achievement of satisfaction

iv. The need for flexibility to the official schedule.

The determination of the theme is formed from the process of data analysis derived from five participants. The first step of the analysis process is determined first keyword each participant, then combined into categories. Further analysis of categories that have similar meanings combined in a theme Tables 2-4.

Table 2 Keyword list study phenomena experience of primary nurse in applying primary method

The Primary nurse is only in the morning service

There should be day and night service

Late evening we appointed the person in charge

The number of nurses is sufficient

Number of patients: primary nurse I: 7-8

Cooperation with other professions

Lack of training related to primary methodes

It should be 5 to 6 of our patients

Hack it

Introduce myself

Ask a complain

Ask for certainty or validation

Comprehensive

Create an intervention 
Table Continued....

Action plan

Create NCP

PA can call the afternoon and evening PN

Collaboration with other medical teams

Other health workers

PA is incapable of action

Ask back to PA

Check the documentation

Discharge planning

Explanation to family

Explanation to patient

Clinical science is more explored

Discussion with other health teams

Full trust manage the patient

Maintenance is better

Reword

Master the patient's complaints

Intertwined cooperation with the PN

Mutual respect

Focused on the client

More comprehensive in patients

Patient's family more freely asked

Patient has his heart

From the questionnaire the patient said satisfied

It should be 5 to 6 of our patients

Previously we managed patients I0-II

Table 3 List of categories of study phenomena experience of primary nurses in applying primary care nursing methods

The nurse's perception of the official schedule

The nurse's perception of man power

Requirement to be a primary nurse

Conduct a more comprehensive review

Objectives and action plan according to the patient's condition

Communicate and coordinate

Evaluate

Direct education

The benefits of nurses

Patient benefits
Table 4 List of themes study of phenomena experience of primary nurses in applying primary methods

$$
\begin{aligned}
& \text { The ability to manage patients } \\
& \text { Competent care for patients }
\end{aligned}
$$

The need for the flexibility of the official schedule

Achieving satisfaction

\section{Discussion}

In this research, the four main themes of the theme of this research are:

i. The ability to manage the patient

ii. Competent care for patients

iii. Achievement of satisfaction

iv. The need for the flexibility of the official schedule.

\section{The ability to manage patients}

The results of the study explained that the nurse's perception of employment, said that the number of nurses is sufficient with the number of primary nurse apprentices 1: 7-8, before the primary nurses manage patients from 10 to 11 patients. The primary nurse in this neuro room lacks training on the primary method. Related to the implementation of the primary method in the neurological space of Bukittinggi West Sumatra Hospital has not been in accordance with the theory because of the lack of understanding of primary nurses on the implementation of the primary method of perception that is not in accordance with the theory of the number of primary care personnel with the patient, and the lack of nurses received training related to the implementation Primary method.

Result of research about primary nurse perception about manpower got four participants say primary nurses manage patient 7-8 people, and declare is enough. In contrast to that described by Sudarsono ${ }^{10}$ that the task of a primary nurse should manage 4 to 6 patients. The primary nurse perception in this study is not yet compatible with Marquis et al. ${ }^{3}$ theory where, the participants stated that the number of primary nurses is sufficient with the ratio of 1-7 to 8 karna before this primary nurse only amounted to 3 people and manage patient 10 11 patients, so According to participants feel now more workload is reduced. The primary nurse theoretically manages 4-6 patients.

The nurse's perception in understanding the implementation of the primary method is influenced by the lack of training related to the primary method. This is in accordance with the Directorate General of Medical Services MOH RI (2000) which states one of the important efforts to improve human resources of health personnel is applied research and training both managerial and technical functional so that the ability of hospital personnel (nurses) increases to overcome all rapid development And efficient in competing in other hospitals.

According to Randal states that the training of effective nurses is one effort in the framework of improving and developing the ability of human resources Hospital. Training is a means of management to improve the knowledge and skills of nurses so that they have the skills, knowledge, mental and personality in accordance with the expected, both theoretically and by a predefined standard. In order for an effective training, all steps of the training activities developed 
must be an integrated activity, so as to provide optimal results. So also with the training of primary methods at Bukittinggi West Sumatra Hospital, the training of primary methods should be given equally and continuously to all primary nurses who are in the neurology room of Bukittinggi West Sumatra Hospital.

\section{Competent care for the patient}

This study demonstrates that primary nurses are competent in treating patients from having more comprehensive assessments ranging from grammar, introducing themselves, asking for complaints, asking for certainty, reviewing head toe, and in terms of objectives and action plans ranging from intervention, Action, then the primary nurse's responsibilities of communicating and coordinating from PA can communicate via afternoon and evening PN telecommunications, collaboration with other medical teams, other health workers and subsequent primary responsibilities is to evaluate by asking back to the PA and the patient as well as the Documentation Check and The last of the primary nurse's responsibilities is direct education by primary nurses.

By giving it layout planning, explanations to the family and explanations. The primary nurse's responsibility is to receive the patient and examine the patient's needs seriously, plan and plan for nursing, implement the plans he has built during his service, communicate and coordinate services provided by other disciplines and other nurses, Pulang, referral to social workshops, contacts With social institutions in the community, making hospital schedules, and residence. ${ }^{3,5}$

Research Bimo application of primary method by primary nurse and nurse assosiet in giving nursing care either observation action, collaboration conducted by primary nurse, action of giving medical therapy, giving health education have been done optimally proven from complete documentation from assessment to With an evaluation of the emerging patient response. Implementation of primary responsibilities in the neurological space of the west sumatra Hospital is in accordance with the theory seen from the start of the assessment that begins the process of granting patients complaints, introducing themselves through therapeutic greetings, validating the patient's complaints with head toe-toe physical examination.

Primary nurses also formulate goals and action plans ranging from making diagnoses, objectives and outcome criteria as well as nursing action plans. In the case of execution of duties and responsibilities of communication and coordination, primary nurses collaborate with other medical teams to meet the needs of patients, and at any time primary nurses may be contacted by the PA in relation to nursing care. Implementation of duties and responsibilities in evaluating the primary nurse also asks back to the nurse the executive has completed its work and the primary nurse also checks the documentation done by the nurse executing and execution of duties and responsibilities of the primary nurse in counseling by giving the planning to go home to family and patient start Patients entering until the patient returns, and provide family and patient explanations.

\section{Achieving satisfaction}

From the results of this study shows the achievement of selfsatisfaction of primary nurses started from the benefits for the nurses include more clinical science eksplorlah, discussions with other health teams, full belief manage the patient, better care, reward, mutual respect, master complaints of patients and established cooperation with PN. And self-satisfaction achieved by primary nurses also from the benefits for patients include, patient-focused, more comprehensive in patients, families more freely asked, the patient yielded his contents and the results of the questionnaire expressed satisfaction. Job satisfaction is a pleasant emotional state or a general attitude toward the difference in rewards received from what should be received, as well as on job factors, self-adjustment and individual social relationships outside the workplace. ${ }^{11}$

Meanwhile, according to research Adriani ${ }^{7}$ found differences in nurse job satisfaction before and after the application of the primary method. A conducive working atmosphere where supporting facilities and infrastructure, comfortable environment, employee relations, supervisors and subordinates harmoniously will greatly affect the work satisfaction of nurses. All participants expressed satisfaction with the implementation of primary methods seen from the benefits gained from nurses and patients such as full trust in managing patients, mutual respect, cooperation with Asossiet nurses, Reword in financial form because it is included in extrinsic motivation which one will spur more nurses Active in providing nursing care.

\section{The need for the flexibility of the official schedule}

The results of this study indicate that the need for the flexibility of the official schedule can be seen from the perception of the official schedule stated that the primary nurse such as primary nurse only in the morning service only, the primary nurse must have the service of day and night, evening and night we appointed the responsible person is needed by the nurse. They need an office schedule other than the morning service.

According Robbin ${ }^{12}$ that perception as an individual process organizes by interpreting the inpresi sensinya in order to give meaning to the surrounding environment. While Toha ${ }^{13}$ explains that perception is essentially a cognitive process experienced by everyone in understanding information about the environment, whether through sight, hearing, appreciation, feeling and smell.

The management approach (especially nursing management) is one of the professional values required to implement professional nursing practice. According to Gillies. ${ }^{14}$ management is defined as a process of completing work through others, while nursing management is a process of working through nursing staff members to provide professional nursing care.

Associated with the implementation of primary methods in the neurological space of Bukittinggi West Sumatra Hospital has not been in accordance with the theory because of the lack of understanding of primary nurses on the implementation of primary methods, perceptions that are inconsistent with theories concerning service scheduling. The results of this study, not in accordance with Marguis and Huston which states that primary nursing is a method of providing nursing care where primary care nurses are responsible for 24 hours on the planning of evaluating one or more patients from hospital admissions until the patient is declared home. During the working hours the primary nurse provides total patient care for the patient. When the primary nurse is not on duty, the care is delegated to the asbestos nurse following the nursing plan that has been prepared by the primary nurse. According to research Sella et al. ${ }^{15}$ also states that the implementation of primary nurse duties assisted by the presence of nurses assosiet. The assosiet nurse collaborates with the primary nurse by supporting and implementing all decisions and interventions planned by the primary nurse 
So the perception of primary nurses in the neurological space of Bukittinggi West Sumatra Hospital has not been in accordance with the theory and research described above. Primary nurses state that primary nurses should be on duty in every shift and they do not yet understand that the duties of the primary nurse can be delegated to the assosiete nurse as long as the primary nurse is not in place. While some participants said that when the primary nurse is not in day and night service then all duties and responsibilities of primary nurses in handed or appointed responsible to the nurse assosiet. ${ }^{16}$

\section{Conclusion}

Based on the results of research and discussion in the previous chapter, it can be concluded that the experience of primary nurses in applying primary nursing care method is the ability to manage patients in terms of nurse perception of the workforce. ${ }^{17-20}$ In caring for the patient, the nurse feels that the nurse's responsibility is competent in treating the patient starting the assessment, establishing the diagnosis, objectives, action plan, evaluation and counseling as well as the satisfaction of the nurses in terms of the nurse and patient's perceived benefits and the flexibility of the service schedule in terms of the nurse's perception Regarding scheduling services. ${ }^{21-22}$ This means that the Hospital is expected to make a policy such as conducting a refresher on knowledge or skills through training related to nurse knowledge improvement on the primary nursing care method and conducting comparative studies of hospitals that actually apply the primary nursing care method, For the next researcher conducting qualitative research about the benefits of applying primary nursing care method so that the participant is not the primary nurse only but Head Section, Kabid can be involved.

\section{Acknowledgements}

Along with the completion of this research, researchers would like to thank all parties who have supported and involved for the implementation of this research. Hopefully all the poured knowledge, all the energy that is spilled, and the abundant support can be worth the deeds in the sight of Allah. In addition, the researchers also hope the results of research is useful to improve the treasures of various parties. Amiin.

\section{Conflict of interest}

The author declares no conflict of interest.

\section{References}

1. Sumijatun. Konsep dasar menuju keperawatan profesional. Trans Info Media, Jakarta, Indonesia: Springer; 2010.

2. Swansburg RC. Pengantar kepemimpinan \& manajemen keperawatan untuk perawat klinis. Jakarta, Indonesia: Springer; 2000.

3. Marguis BL, Huston CJ. Kepemimpinan dan manajemen keperawatan. Jakarta, Indonesia: Springer; 2010.
4. Nursalam. Manajemen Keperawatan: Aplikasi dalam praktek keperawatan profesional. Salemba Medika, Jakarta: Springer; 2012.

5. Simamora RH. Buku Ajar Manajemen Keperawatan. EGC, Jakarta, Indonesia: Springer; 2012.

6. Setyowati A. Pengaruh Penerapan metode Penugasan Modifikasi Tim Primer terhadap Kinerja perawat pelaksana di ruang rawat inap RS. Perpustakaan Universitas Indonesia, Indonesia: Springer; 2001.

7. Adriani L, Armanu, Kuwantoro. Kepuasan kerja perawat pada aplikasi metode tim primer dalam pelaksanaan tindakan asuhan keperawatan di Rumah sakit Dr. Saiful Anwar Malang. Jurnal Aplikasi Manajemen. 2012;10(2):419-424

8. Afiyati Yati. Metode Penelitian Kualitatif dalam Riset Keperawatan. Rajawali Pers, Jakarta, Indonesia: Springer; 2014.

9. Moleong Lexy J. Metode Penelitian Kualitatif. Indonesia: Bandung: Remaja Rosdakarya; 2005.

10. Sudarsono RS. Berbagai model praktek keperawatan profesional di Rumah sakit. Makalah seminar dan semiloka MPKP II. Jakarta, Indonesia: Springer; 2000.

11. Anoraga P. Psikologi kerja. PT Rineka Cipta, Jakarta, Indonesia: Springer; 1998.

12. Robbin. Perilaku organisasi: Konsep, Kontroversi, Aplikasi. Edisi kedelapan. Terjemahan. Jakarta, Indonesia: Springer; 2001.

13. Toha RM. Perilaku organisasi: konsep dasar dan aplikasinya. Jakarta. Indonesia: Raja Grafindo Persada; 1995.

14. Gillies DA. Manajemen Keperawatan. EGC, Jakarta, Indonesia: Springer; 1998.

15. Sella S, Macleod J. A hermeneutic analysis of the lived experiences of associate nurses. Journal of clinical Nursing. 1995;4(1):55-60

16. Hongwei $\mathrm{H}, \mathrm{Hu} \mathrm{S}$, Thobaben $\mathrm{M}$, et al. Continius primary nursing care increases satisfaction with nursing care and reduces postpartum problems for hospitalized pregnant women. Contemporary Nurse. 2011;37(2):149-159.

17. Jellinek. Primery Nursing: Psychological Implikasions. Nursing management. 1994;25(5).

18. Muninjaya AG. Manajemen kesehatan. EGC, Jakarta, Indonesia: Springer; 2004.

19. Rusmianingsih N. Hubungan penerapan pemberian asuhan keperawatan tim dengan kepuasan kerja perawat di instalansi rawat inap RS Umum Kabupaten Tanggerang. Indonesia: Springer; 2012.

20. Ruch Shirly. Primary Nursing: A call for Clarity, Empowerment, and Accountability. Creative Nursing. 2012;18(4):175-176.

21. Universitas Andalas. Pedoman Penulisan Proposal Penelitian dan Tesis. Padang. Universitas Andalas,Indonesia: Springer; 2014.

22. Wibowo A. Metodologi Penelitian Praktis Bidang Kesehatan. Rajawali Pers, Jakarta, Indonesia: Springer; 2014. 